Две выделенные группы фразеологической неологики требуют дифференцированного этимологического подхода. Для заимствований желательна не только констатация языкового источника, но и обращение к его истории в языке-доноре. Для русских фразеологических неологизмов необходима углубленная социальная и лингвокультурологическая справка, подкрепляющая собственно лингвистическую интерпретацию.

Примеры предлагаемых подходов будут представлены в докладе.

РЯ — Русский язык : энцикл. / гл. ред. Ю. Н. Караулов. 2-е изд., перераб. и доп. М., 1997.

DOI $10.31168 / 7996-2700-3.79$

\author{
А. Б. Мороз \\ Национальный исследовательский университет \\ «Высшая школа экономики» \\ Российский государственный гуманитарный университет \\ Москва, Россия \\ abmoroz@yandex.ru
}

\title{
Святке: биография несуществующего демона
}

В русской фольклористике с рубежа XIX-XX вв. распространены сведения о демоне, название или имя которого дается то с прописной, то со строчной буквы: Святке. Одно из первых его упоминаний содержится в [Георгиевский, 1902, 61], наиболее поздние упоминания в [Конкка, 2018]. Представления об этом демоне, известные на Европейском Севере России, преимущественно в Карелии, сформировались, вероятно, не без влияния финно-угорской (карельской) демонологии.

Как можно судить по имени / названию, демон активизируется в святочный период. Он пугает гадающих или нападает на них, а также дает гадающим ответ на вопрос о будущей судьбе [см.: Власова, 1998, 471-472].

В источниках с дореформенной орфографией демоним пишется с конечной буквой $b$, место ударения не определено. Он склоняется по *-o-типу, т. е., например, как силок: род. п. святка́. Авторы публикаций, посвященных данному персонажу, более или менее дословно (C) Моpoз А. Б., 2019 
воспроизводят фрагмент из статьи А. Георгиевского, иногда дополняя его другими - аналогичными или похожими - контекстами и сопоставляя образ святочного демона с лешим, чертями, дьяволом, которые могут выступать в подобных ролях.

Ни у кого из авторов публикаций, рассматривавших святке, не вызвала недоумения странная морфология демонима, совершенно не типичная для русского языка и противоречащая правилам русской грамматики. Единственно возможный вариант окончания -е (-ъ) для существительного в им. п. - двойственное число, однако его распространение в русском языке, в том числе в севернорусских говорах, не засвидетельствовано (за исключением окончания твор. п. -ама, используемого в мн. ч. вместо -ами, и словоформы муде, впрочем, тоже не слишком распространенной в этом виде).

Текст, опубликованный А. Георгиевским в «Олонецком сборнике», очевидно, представляет собой не полевую запись, в которой говорит сам информант, а пересказ автора публикации. Мотивы, связанные со святке, в этом тексте таковы:

- во время гадания со шкурой демон не может переступить магический круг, нарисованный гадающими;

- святке таскает шкуру, на которой сидят гадающие, за хвост, потому что он оказался за пределами магического круга;

- демон надевает валенок на голову гадающей девушки; срывает у других гадающих горшки с голов, думая, что это сами головы.

Еще один мотив приводится в разделе, посвященном святке, но без упоминания самого демона: гадающему в поле показался воз с грузом - когда тот подошел к возу, то обнаружил в нем шелк и разбогател.

В полевых материалах, записанных в ряде севернорусских регионов, действительно упоминается демон, активность которого приходится исключительно на период Святок и который в известном смысле участвует в гаданиях, в том числе и описанным выше образом. Обычно его именуют общими терминами - как правило, в мн. ч.: биси, черти . Среди наименований этого демона встречается и свя́тки́. Диалектные словари, описывающие севернорусские говоры, если и упоминают о демоне с названием, образованным от календарного периода, то только в этой форме мн. ч.

В полевых материалах, имеющихся в нашем распоряжении, в том числе в материалах архива Лаборатории фольклористики РГГУ (Арх.: 
Вел., Карг, Леш., Нянд., Прим.), наиболее частотны два контекста, в которых упоминается этот демон. Первый - это описываемое А. Георгиевским гадание на росстани, когда гадающие, сидя на шкуре, очерчивают вокруг себя линию с помощью кочерги, сковородника или головешки. При этом произносится приговор, содержащий такие слова: «...встань стена каменная от земли до неба, чтобы не пройти, не проехать ни пешему, ни конному, ни святку́ востроголовому». Второй контекст связан с ночью накануне Крещения, когда святки поезжают, т. е. уходят. В это время девушкам рекомендуется выставлять на улицу перед домом мутовки - в надежде, что святки на них шелка намотают.

Можно предположить, что рассматриваемая лексема имеет недостаточную парадигму, с отсутствующей формой номинатива ед. ч. Однако в любом случае она не может быть «восстановлена» в том виде, в котором приводится в работах А. Георгиевского и его последователей. Гораздо более закономерными выглядели бы гипотетические формы *свято́к или *святко́, однако они не зафиксированы. Подобная ситуация объяснима, как представляется, омонимией демонима и хрононима - притом что хрононим представляет собой имя pl. $t$., а одноименные демоны, упоминаемые в большинстве контекстов, также представлены множественно. В гадательном приговоре отражено едва ли не единичное употребление слова в ед. ч. - вполне возможно, что это окказионализм.

Если рассматривать фольклорно-мифологические параллели, то можно предположить, что святки тождественны или близки шуликунам - на это, в частности, указывают остроголовость и мотание шелка на мутовки, что приписывается и шуликунам. В то же время А. Конкка видит в названии святочного демона параллель с карел. цъюнда 'домовой' [Конкка, 2018]. Перенос хрононима на демона, активность которого связана с соответствующим календарным периодом, выглядит вполне логично, тем более что в одном из распространенных контекстов (святки поезжают) различие демонов и праздников нейтрализуется. Как можно думать, словоформа святке есть не что иное, как искусственный конструкт, созданный А. Георгиевским, которому был необходим номинатив для изложения сюжетов о демоне. Причина «несообразности» этого конструкта пока остается непонятной вероятно, это некий курьез, раскрыть который было бы возможно при наличии рукописного оригинала заметки. 
Что касается написания названия демона с прописной буквы, то оно, видимо, обусловлено влиянием сложившейся еще в «мифологических» сочинениях XVIII в. традиции писать таким образом названия демонов - это объяснимо стремлением поставить леших, домовых и т. п. в один ряд с языческими богами.

Власова М. Н. Русские суеверия : энцикл. словарь. СПб., 1998.

Георгиевский А. Народная демонология // Олонецкий сборник: Материалы для истории, географии, статистики и этнографии Олонецкого края. Вып. 4. Петрозаводск, 1902. С. 53-61.

Конкка А. П. Святке - мифологический персонаж зимних Святок на востоке Олонецкой губернии и его карельские параллели // Уникальное и типичное в славянском фольклоре / отв. ред. А. Б. Мороз. М., 2018. В печати.

DOI 10.31168/7996-2700-3.80

\author{
И. И. Муллонен*, Е. В. Захарова** \\ Петрозаводск, Россия \\ *mullonen@sampo.ru \\ **katja.zaharova@mail.ru
}

Институт языка, литературы и истории КарНЦ РАН

\title{
Проблемы интеграции прибалтийско-финских топонимов в официальное русское употребление*
}

Прикладная топонимика призвана решать насущные практические задачи, устанавливающие нормы орфографии, орфоэпии, образования грамматических форм топонимов, имеющих официальное бытование. Вопросы стандартизации стоят особенно актуально в национальных регионах России, где решается задача интеграции национальных топонимов в официальное русское употребление.

В Карелии, благодаря многовековому взаимодействию прибалтийско-финской и русской топосистем, сложились многие естественные нормы, образцы адаптации карельской / вепсской топонимии

\footnotetext{
* Публикация подготовлена в рамках выполнения проекта РФФИ № 19-012-00068А «Ойконимическая система южной Карелии: на стыке традиций и инноваций».
}

(С) Муллонен И. И., Захарова Е. В., 2019 